\title{
Ultra-fast high-resolution agarose electrophoresis of DNA and RNA using low-molarity conductive media
}

\author{
Jonathan R. Brody, Eric S. Calhoun, Eike Gallmeier, Talisa D. Creavalle, \\ and Scott E. Kern \\ The Johns Hopkins University School of Medicine, Baltimore, MD, USA \\ BioTechniques 37:598-602 (October 2004)
}

Current DNA electrophoretic solutions employ high ionic concentrations and require long electrophoretic run times. Here we demonstrate that high and low molecular weight doublestranded DNA, single-stranded DNA (ssDNA), and RNA can be separated rapidly in agarosebased low-molarity conductive media. Separation of small DNA fragments was optimized by substituting 1-mM solutions of alkali metals or a nonbiological amine that distributed voltage with a minute current. These ultra-dilute solutions can separate DNA at least 15-fold faster. Low-molarity media at 5-10 mM adequately separated RNA and larger DNA fragments as well. These novel media reduce the Joule heating of the electrophoretic system and allow for easy-to-use, ultra-fast separation of DNA fragments.

\section{INTRODUCTION}

Recently, we reported that substituting sodium for Tris reduced the current and temperature of electrophoresis (1). Tris has been the dominant cation of choice for DNA electrophoresis for the last 30 years (2-6) and was adopted expediently from existing RNA and protein methodology. Current media, Tris-acetic acid plus ethylenediaminetetraacetic acid (EDTA) (TAE) and Tris-boric acid EDTA (TBE), contain 40-90 mM concentrations of Tris, generally take nearly $2 \mathrm{~h}$ to separate DNA fragments, and often require substitution of polyacrylamide, a polymer that is more difficult to work with, in place of agarose when separating DNA fragments smaller than $300 \mathrm{bp}$. Tris is mostly ionized under electrophoretic conditions, requiring corresponding anion concentrations. Prior attempts to find a replacement for Tris perhaps failed because other cations at similar concentrations generated excessive amounts of current and heat.

Based on our success with simplified sodium-based solutions for DNA electrophoresis (1), we explored other cations, anions, and concentrations. Traditionally, for high molecular weight DNA separation, investigators have relied on low-percentage agarose using acetate as the preferred anion. RNA electrophoresis usually employs sodium as the cation, with 4-morpho- linepropane sulfonic acid (MOPS), acetate, and EDTA as anions $(2,3)$. We therefore explored simplified conductive media lacking Tris, MOPS, and EDTA in specialty applications to resolve smaller and larger fragments of DNA and to separate RNA.

\section{MATERIALS AND METHODS}

Gels were $1.0 \%$ agarose (Type I low electroendosmosis; Sigma, St. Louis, MO, USA) unless otherwise indicated and contained $0.1 \%$ ethidium bromide (Fisher Scientific, Fairlawn, NJ, USA). The power source displayed current flow (milliamps) at set voltages $(250,300$, and 1000 volts $(\mathrm{V}) . \Delta \mathrm{T}$ (temperature change, ${ }^{\circ} \mathrm{C}$ ) was calculated by subtracting the initial from the final temperature of the media in the anodic chamber. All electrophoretic runs used the Horizontal Mini-Gel System (model MGU-500 for DNA, MGU-200T for RNA; CBS Scientific, Del Mar, CA, USA) and had $650 \mathrm{~mL}$ total volume of medium in the reservoirs. Gels were $10 \mathrm{~cm}$ in length. The $1 \mathrm{~Kb}$ Plus DNA LadderTM (Invitrogen, Carlsbad, CA, USA) and $20 \mathrm{bp}$ DNA ladder (GenSura, San Diego, CA, USA) were loaded as indicated. For DNA, loading media included Orange G and $10 \%$ glycerol in solutions to match the cognate $1 \times$ conductive media in use. Chemicals were purchased from Sigma or USB (Cleveland, OH, USA).

Short oligomers of single-stranded DNA (ssDNA) were separated in $1 \mathrm{mM}$ lithium boric acid medium. A 35-bp oligomer was mixed in parallel with 36 , 38 , and 45 bp oligomers (40 ng each), respectively, and heated to $70^{\circ} \mathrm{C}$ for 5 min to denature potential dimers. Samples were loaded at $37^{\circ} \mathrm{C}$ and separated for $25 \mathrm{~min}$ at $29 \mathrm{~V} / \mathrm{cm}$.

For RNA gel electrophoresis, an RNA ladder (no. 361; New England Biolabs, Beverly, MA, USA) was used. For each run, $200 \mathrm{ng}(0.4 \mu \mathrm{L})$ were added to $1.8 \mu \mathrm{L}$ of loading medium (4.6\% glycerol, $22 \%$ formaldehyde, $20 \%$ formamide, and $50 \mu \mathrm{g} / \mathrm{mL}$ ethidium bromide) were denatured at $70^{\circ} \mathrm{C}$ for $2 \mathrm{~min}$, placed on ice for $2 \mathrm{~min}$, and loaded onto denaturing gels containing $1 \%$ agarose, $0.67 \%$ formaldehyde, and either $5 \mathrm{mM}$ sodium boric acid or 5 $\mathrm{mM}$ lithium acetate in the gel and reservoirs. Gels were run at $400 \mathrm{~V} \mathrm{(40} \mathrm{V/}$ $\mathrm{cm})$ for $10 \mathrm{~min}$. Current was observed by methods similar to those described for DNA electrophoresis.

\section{RESULTS AND DISCUSSION}

Sodium boric acid (10 $\mathrm{mM}$ sodium) permitted high-voltage rapid DNA electrophoresis (1). Empirically, in specialty applications, we show that it is possible to further reduce the ionic concentrations and current of conductive media by another 5- to 10-fold. Salt solutions of alkali metals (lithium boric acid, rubidium boric acid, potassium boric acid, cesium boric acid) and a simple, nonbiologic buffer amine (ethanolamine with boric acid) were tested at various concentrations. At $1 \mathrm{mM}$ cation concentration, DNA fragments were separated with minimal conductivity (Figure 1A). Notably, these solutions separated small DNA fragments at a very high voltage (Figure 1B, 1000 $\mathrm{V}, 100 \mathrm{~V} / \mathrm{cm}$ ). These low-concentration solutions did not generate significant heat in an electrophoretic system, unlike common electrophoretic media, and thus were run roughly 15 -fold faster than is conventional practice (Figure 1A, TAE and TBE run at $5-10 \mathrm{~V} / \mathrm{cm}$; new conductive media, up to $150 \mathrm{~V} / \mathrm{cm}$; data not shown). Furthermore, these low-molarity media served well in separating small DNA fragments in agarose gels that normally 
would require polyacrylamide (Figure 1, A and C). Electrolyte exhaustion was measured by observing the current over the course of the electrophoretic runs; the current of the 1-mM solutions did not drop more than $15 \%$ during these runs (Figure 1, A and B).

Lithium boric acid outperformed other alkali metal media tested in its low conductivity and minimal heating with

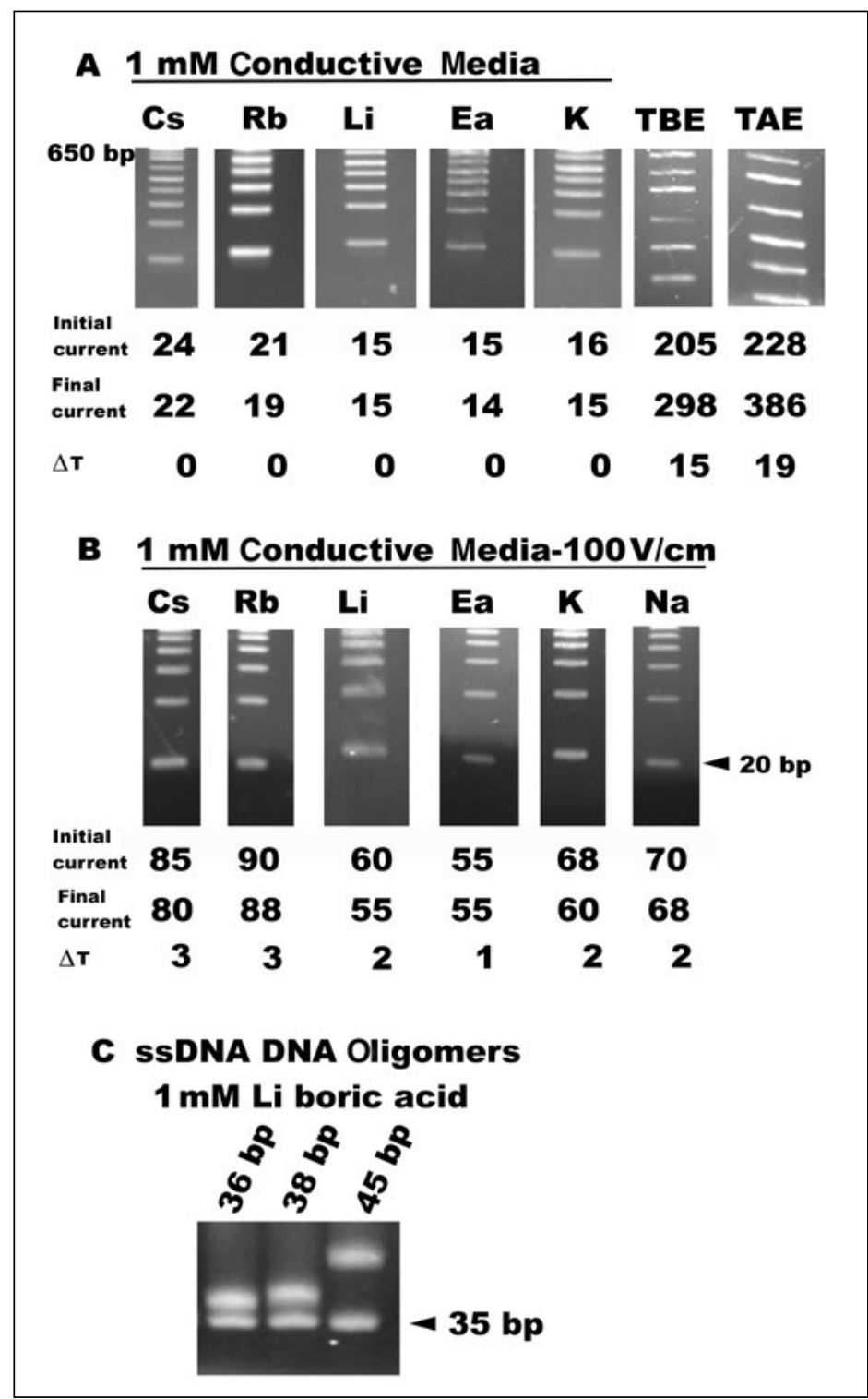

Figure 1. One millimolar conductive media in $\mathbf{3 . 0 \%}$ agarose gels. All cations were paired with boric acid. Cations are represented by their elemental symbol, except for ethanolamine (Ea). $\Delta \mathrm{T}$ (temperature change) is given in degrees Celcius and current is given in milliamperes. (A) Resolution at $100 \mathrm{bp}$. Two hundred fifty volts (V) were applied for $25 \mathrm{~min}$. The $1 \mathrm{~Kb}$ Plus DNA Ladder had fragments at 100, 200, 300, 400, 500, and 650 bp (and larger, cropped). Under these conditions, Tris-acetic acid ethylenediaminetetraacetic acid (EDTA) (TAE) and Tris-boric acid EDTA (TBE) gels had partial melting (data not shown). (B) Resolution at $20 \mathrm{bp}$. A very high voltage $(1000 \mathrm{~V})$ was applied for $5.5 \mathrm{~min}$ (as compared to the conventional $90 \mathrm{~min}$ ). The GenSura ladder had fragments at 20,40,60,80, and $100 \mathrm{bp}$. TAE and TBE gels were unable to be run due to the wattage limitations of existing power supplies. The $\mathrm{pH}$ of the conductive media at $1 \mathrm{mM}$ was approximately 8.2. (C) Resolution at $1 \mathrm{bp}$. Singlestranded DNA (ssDNA) oligomers were run on $3 \%$ agarose gels at $29 \mathrm{~V} / \mathrm{cm}$ for 25 min. Each lane was loaded with a different size of oligomer mixed with a 35-oligomer. A TAE gel run under the same conditions melted $\left(55^{\circ} \mathrm{C}\right.$ after $\left.20 \mathrm{~min}\right)$. A TBE gel was partially melted and showed fuzzy, unresolved bands $\left(>50^{\circ} \mathrm{C}\right.$ after $\left.20 \mathrm{~min}\right)$. comparable resolution (Figure 1) when tested at 0.5 to $10 \mathrm{mM}$. At $1 \mathrm{mM}$, lithium boric acid (3.0\% agarose gel) was able to resolve the differences between ssDNA oligomers of 35, 36, 38, and 45 bp (Figure $1 \mathrm{C}$ ). Gel purification of an oligomer in $1 \mathrm{mM}$ lithium boric acid yielded high recovery of the ssDNA fragment (Spin$\mathrm{X}^{\circledR}$; Corning Costar, Cambridge, MA, USA) (data not shown). Low-molarity media readily permitted the preparation of these high-density (3.0\% agarose) gels (Figure 1C).

Although boric acid provides an exceptional anion for DNA electrophoresis

\section{A $5 \mathrm{mM} \mathrm{Li}$ acetate- $30 \mathrm{~V} / \mathrm{cm}$}

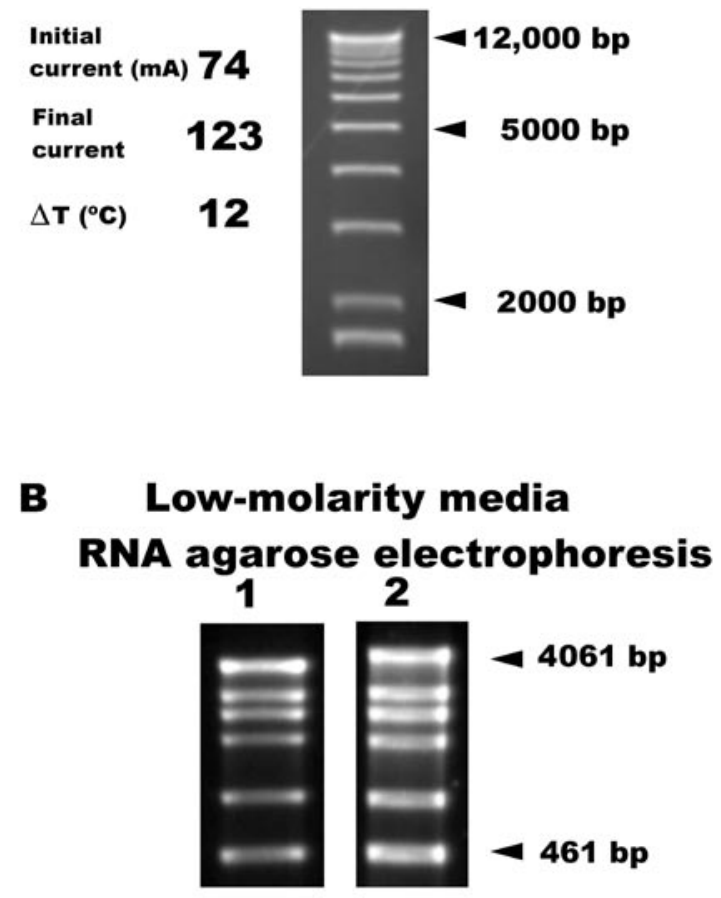

Figure 2. Separation of high molecular weight DNA and RNA using low-molarity conductive media. (A) Resolution at $1000 \mathrm{bp}$. A high voltage $(300 \mathrm{~V})$ was applied for less than $30 \mathrm{~min}$. The $1 \mathrm{~Kb}$ Plus DNA Ladder comprises $1.6 \mathrm{~kb}$ and $2-12 \mathrm{~kb}$ in $1-\mathrm{kb}$ increments. The $\mathrm{pH}$ of $5 \mathrm{mM}$ lithium acetate was approximately 6.5. Tris-acetic acid ethylenediaminetetraacetic acid (EDTA) (TAE) and Tris-boric acid EDTA (TBE) gels melted under the same conditions. (B) Low-molarity media used to separate RNA. Agarose-formaldehyde gels (1.0\%) were run at $40 \mathrm{~V} / \mathrm{cm}$ for $10 \mathrm{~min}$. The New England Biolabs ladder had fragment sizes of 461 to 4061 bases, as indicated. Lane 1 represents a $5-\mathrm{mM}$ lithium acetate agarose gel, and lane 2 represents a 5 -mM sodium boric acid gel ( $\mathrm{pH}$ 6.0). The initial current for the sodium boric acid medium was $44 \mathrm{~mA}$ and the final current was $47 \mathrm{~mA}$. The $\Delta \mathrm{T}$ (temperature change) was $8^{\circ} \mathrm{C}$. The initial current for the lithium acetate medium was $56 \mathrm{~mA}$, and the final current was $80 \mathrm{~mA}$. The $\Delta \mathrm{T}$ was $9^{\circ} \mathrm{C} .1 \times$ MOPS (20 mM MOPS, $7 \mathrm{mM}$ sodium, $1 \mathrm{mM}$ EDTA) at the same voltage had resolution equivalent to novel media (data not shown), yet had an initial current of $93 \mathrm{~mA}$ and a final current of $119 \mathrm{~mA}$; the $\Delta \mathrm{T}$ was $15^{\circ} \mathrm{C}$. MOPS, 4-morpholinepropane sulfonic acid. 
(1-3), we found that alternative nonborate anions produced improved separation of high molecular weight $(>2.0 \mathrm{~kb})$ DNA fragments (data not shown). Lithium acetate $(1 \times ; 5 \mathrm{mM})$ produced low current and heat, thus allowing for fast separation of the longer DNA fragments (over $3000 \mathrm{bp}$ ) in $1.0 \%$ agarose gels (Figure 2A). In comparison, TAE and TBE gels melted within 30 min at such high voltage (Figure $2 \mathrm{~A}, 30 \mathrm{~V} / \mathrm{cm}$ ).

Low-molarity media were also successful in separating RNA in agarose gel electrophoresis (Figure 2B). Sodium boric acid $(0.5 \times ; 5 \mathrm{mM}$, pH 6.0$)$ and lithium acetate $(5 \mathrm{mM})$ resolved RNA within 10 min (Figure 2C, $400 \mathrm{~V}$, $40 \mathrm{~V} / \mathrm{cm}$ ). These low-molarity media resolved RNA under lower heat and conductive conditions than the conventional MOPS medium (Figure 2B).

A positive runaway feedback loop exists in DNA electrophoresis between temperature and current when using Tris-based solutions (Figure 1A, TAE and TBE) (1,7-10). New conductive media mitigate this feedback loop and allow for ultra-fast separation of small and large DNA and RNA fragments in an easy-to-use agarose system (Figures 1 and 2). Lithium had the lowest current of the alkali metal series, consis- tent with its larger shell of hydration. Conversely, and as expected, cesium and rubidium had the highest conductivity due to their smaller radii of hydration (Figure 1). One millimolar solutions performed well in electrophoresis, irrespective of concern for buffering capacity, and thus it is best to label these solutions as conductive media rather than as buffers (10).

For standard applications of slab gel DNA electrophoresis (100 bp to $5.0 \mathrm{~kb}$ separations), we recommend the use of $10 \mathrm{mM}$ sodium boric acid (1). In special situations, such as high-resolution separation of longer DNA fragments $(>3.0 \mathrm{~kb})$, we recommend $5 \mathrm{mM}$ lithium acetate (Figure 2A). In addition, $5 \mathrm{mM}$ sodium boric acid and $5 \mathrm{mM}$ lithium acetate media can be used in place of MOPS for RNA separation (Figure 2B). One millimolar lithium boric acid agarose gels can be used in place of polyacrylamide for the separation of small DNA and ssDNA fragments (Figure 1). Other choices are not precluded, but these appeared optimal under the conditions tested.

Low-molarity media mitigate the positive feedback loop that exists with existing media and can be used to separate very small or large fragments of DNA in agarose gels, outperforming the commonly used media in the aboveexamined applications. These findings should improve the speed, cost-effectiveness, and practicality of many genetic-based investigations.

\section{ACKNOWLEDGMENTS}

This work was supported by $\mathrm{Na}$ tional Institutes of Health grant no. CA62924 to S.E.K.

\section{COMPETING INTERESTS STATEMENT}

J.R.B. and S.E.K. are owners of Faster Better Media LLC and as such receive revenue on sales of products described in this article. This creates a significant financial conflict of interest, which is being managed by The Johns Hopkins University in accordance with its conflict of interest policies. Authors E.S.C., E.G., and T.D.C. have no competing interests.

\section{NOTE ADDED IN PROOF}

Sodium boric acid (10 $\mathrm{mM})$ and lithium acetate $(5 \mathrm{mM})$ were also used in pulsed field gel electrophoresis to speed the migration of 30,000 to 70,000 bp DNA fragments in a Bio-Rad CHEF Mapper ${ }^{\circledR}$ System with sharp resolution (collaboration with Robert C. Ireland, Rhode Island Dept. of Health Laboratories).

\section{REFERENCES}

1.Brody, J.R. and S.E. Kern. 2004. Sodium boric acid: a Tris-free, cooler conductive medium for DNA electrophoresis. BioTechniques 36:214216.

2.Maniatis, T., E.F. Fritsch, and J. Sambrook. 1982. Molecular Cloning: A Laboratory Manual. CSH Laboratory Press, Cold Spring Harbor, NY.

3.Sambrook, J. and D.W. Russell. 2001. Molecular Cloning: A Laboratory Manual. CSH Laboratory Press, Cold Spring Harbor, NY.

4.Aaij, C. and P. Borst. 1972. The gel electrophoresis of DNA. Biochim. Biophys. Acta 269:192200.

5.Hayward, G.S. and M.G. Smith. 1972. The chromosome of bacteriophage T5. I. Analysis of the single-stranded DNA fragments by agarose gel electrophoresis. J. Mol. Biol. 63:383-395.

6.Maniatis, T. and M. Ptashne. 1973. Structure of the lambda operators. Nature 246:133-136.

7.Hjerten, S. 1973. Dedication to Professor Arne Tiselius. Ann. NY Acad. Sci. 209:5-7.

8.Hawcroft, D.M. 1996. Electrophoresis: The Basics. IRL Press at Oxford University Press, Oxford.

9.Allen, R.C. and B. Budowle. 1994. Gel Electrophoresis of Proteins and Nucleic Acids: Selected Techniques. Walter de Gruyter, Berlin.

10.Brody, J.R. and S.E. Kern. Histoy and principles of conductive media for standard DNA electrophoresis. Anal. Biochem. (In press, epub ahead of print 28 July, 2004).

Received 26 April 2004; accepted 1 June 2004.

Address correspondence to Scott E. Kern, 451 CRB, Department of Oncology, The Sidney Kimmel Comprehensive Cancer Center, The Johns Hopkins University School of Medicine, Baltimore, MD 21231, USA.e-mail: sk@jhmi.edu 